WSRC-TR-93-595 (U)

\title{
POTENTIAL FOR EROSION CORROSION OF SRS HIGH LEVEL WASTE TANKS (U)
}

\author{
P. E. Zapp
}

Savannah River Technology Center

Equipment \& Materials Technology Department

Materials Technology Section

Publication Date: January, 1994

\section{Westinghouse Savannah River Company Savannah River Site Aiken, SC 29808}

This document was prepared in connection with work done und $r$ Contract No. DE-AC09-89SR18035 with the U. S. Department of Energy. By acceptance of this document, the publisher and/or recipient acknowledges the U. S. Government's right to retain a nonexclusive, royalty-free license in and to any $c \infty$ yright covering this document, along with the right to reproduce and authorize others to reproduce all or part of the copyrighted material. 


\section{DISCLAIMER}

This report was prepared by Westinghouse Savannah River Company (WSRC) for the Unifed States Depariment of Energy under Confract No. DE-AC09$895 R 18035$ and is an account of work performed under that contract. Nelther the Uniled States Department of Energy, nor WSRC, nor any of their employees makes any warranty, expressed or implied, or assumes any legal liablitiy or responsibility for the accuracy, completeness, or usefulness, of any information, apparatus, or product or process disclosed herein or represents that its use will nof infringe privately owned rights. Reference herein to any specific commercial product, process, or service by trademark, name, manufacturer or otherwise does not necessarily constitute or imply endorsement, recommendation, or fovoring of same by WSRC or by the United States Government or any agency thereot. The views and opinions of the authors expressed herein do not necessarily state or reflect those of the United States Government or any agency thereof. 


\section{APPROVALS}

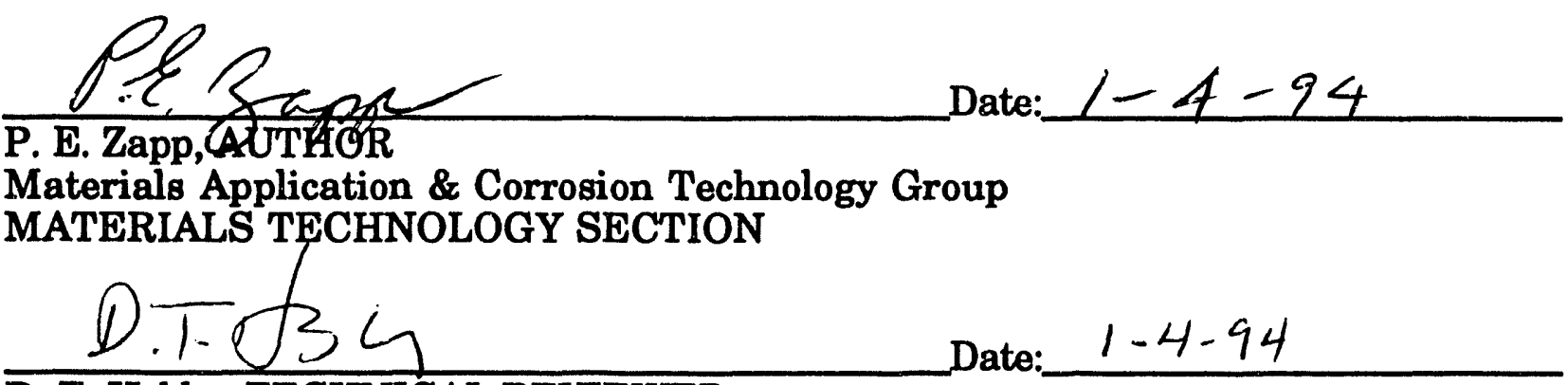

D. T. Hobbs, TECHNICAL REVIEWER

Liquid Waste Processing Group

INTERIM WASTE TECHNOLOGY SECTION

catray $7 y$.

N. C. Iyer, MANAGER

Date: $\quad 1-4-94$

Materials Application \& Corrosion Technology Group

MATERIALS TECHNOLOGY SECTION

7. L. Copalors

T. L. Capeletti, MANAGER

Date: $\quad 1 / 4194$

MATERIALS TECHNOLOGY SECTION

ACCander

Date:

J. Chandler, MANAGER

Technical Support

HIGH-LEVEL WASTE ENGINEERING 


\title{
POTENTIAL FOR EROSION CORROSION OF SRS HIGH LEVEL WASTE TANKS (U)
}

\author{
P. E. Zapp \\ Westinghouse Savannah River Co. \\ Savannah River Site \\ Aiken, SC 29808
}

\section{SUMMARY}

SRS high-level radioactive waste tanks will not experience erosion corrosion to any significant degree during slurry pump operations. Erosion corrosion in carbon steel structures at reported pump discharge velocities is dominated by electrochemical (corrosion) processes. Interruption of those processes, as by the addition of corrosion inhibitors, sharply reduces the rate of metal loss from erosion corrosion. The wellinhibited SRS waste tanks have a near-zero general corrosion rate, and therefore will be essentially immune to erosion corrosion.

The experimental data on carbon steel erosion corrosion most relevant to SRS operations was obtained at the Hanford Site on simulated Purex waste. A metal loss rate of 2.4 mils per year was measured at a temperature of $102^{\circ} \mathrm{C}$ and a slurry velocity comparable to calculated SRS slurry velocities on ground specimens of the same carbon steel used in SRS waste tanks. Based on this data and the much lower expected temperatures, the metal loss rate of SRS tanks under waste removal and processing conditions should be insignificant, i.e. less than 1 mil per year

\section{INTRODUCTION}

The causes of deterioration of engineering materials can be divided into mechanical and chemical modes. The mechanical mode includes erosion by the impact of solid particles, liquids, or gases and abrasive (sliding) wear. Chemical deterioration includes aqueous corrosion and high-temperature oxidation. The interaction of mechanical and chemical modes produces the complex phenomenon of erosion corrosion. According to Fontana and Greene, erosion corrosion is the increase in corrosion rate of metal because of the relative motion between the metal and a corrosive fluid. 1 Erosion corrosion depends upon the removal by the flowing corrosive medium of protective surface films, with the subsequent exposure of fresh reactive metal. The flowing medium can be single phase (liquid) or dual phase (liquid and gas or liquid and solid). The attack tends to be localized, although not to the extent characteristic of pitting or crevice corrosion. ${ }^{2}$

Investigators generally distinguish erosion corrosion from related phenomena, such as cavitation and impingement damage, which are considered to be dominated by mechanical forces. Cavitation is material degradation which arises from the implosion of gas or vapor bubbles in a flowing liquid near a metallic surface. Impingement refers to the impact on a metal of moving liquid droplets entrained in a gas or vapor stream, as in wet steam. Cavitation and impingement damage are responses to forces that exceed the yield strength of metals and thus plastically 
deform them; corrosion is thought to play a relatively lesser role. On the chemical side, erosion corrosion is distinguished from the merely "flow-assisted" corrosion that involves increased mass transfer rates of reactants and corrosion products. Of course, in numerous combinations of ali oys and environments, the boundaries between these classifications may be imprec se.

The extent of erosion corrosion depends upon properties of the material and properties of the flowing medium. Material properties include alloy composition and corrosion resistance, strength, hardness, and nature of surface (protective) films. The fluid properties are temperature and chemistry, phase composition, abrasiveness of suspended particles, velocity, turbulent versus laminar flow, and relative direction of flow with respect to the effected metal surface(s).

This report reviews the available literature on erosion corrosion of carbon steels. Large volumes of radioactive waste sludge must be suspended and transferred for eventual vitrification. The potential for erosion corrosion of carbon steels is evaluated based on the jet mixing in Extended Sludge Processing (ESP) tanks with quad-volute slurry pumps. These pumps deliver the highest velocities of the various pumps in SRS tanks. ${ }^{3}$ Cavitation and impingement damage are not discussed further, since they will not occur under the velocities and slurry compositions expected in SRS waste tanks.

\section{EROSION CORROSION OF CARBON STEELS}

Systematic studies of erosion corrosion in steel began in the 1970s. These studies arose out of interest primarily in two technological areas. The first area is erosion corrosion of steel pipelines and equipment which transport and process aqueous mineral slurries, especially coal slurries. The damage process occurs at ambient temperature with usually aerated solutions. The second area is in relatively pure water systems such as boiler feedwater and secondary water systems of nuclear reactors, where damage occurs at elevated temperatures under usually deaerated conditions. In mineral slurries, the relative importance of the mechanical versus chemical degradation processes is especially variable and depends upon the characteristics of the flowing medium. ${ }^{4}$ The mineral slurry literature is the more relevant to the question of waste tank erosion corrosion.

Among iron-based alloys, carbon steels are much more susceptible to erosion corrosion than even those low-alloy steels with small concentrations of alloying elements. Small concentrations of chromium in steel have been shown to decrease susceptibility. Increasing the chromium content to the levels in the stainless steels substantially improves erosion corrosion resistance. For example, plain carbon steel is extremely susceptible to erosion corrosion in high temperature water or wet steam, while austenitic stainless steels are essentially immune in those environments. ${ }^{5}$ In aerated coal slurry environments, carbon steel experiences from 4 to 10 times the metal loss observed in type 304 stainless steel. 6

Because of the interest in coal liquefaction and coal processing, considerable work has been done on erosion corrosion of steel by coal slurries. In this system it is the oxides which make up the ash content of coal that are responsible for erosion. The 
harder oxides, such as $\mathrm{SiO}_{2}, \mathrm{Al}_{2} \mathrm{O}_{3}, \mathrm{Fe}_{2} \mathrm{O}_{3}$, are the most erosive. ${ }^{7} \mathrm{Fe}_{2} \mathrm{O}_{3}$ and associated compounds make up much of the solids in SRS waste sludge. Erosion corrosion of carbon steel due to coal (and sand) slurries has been shown to be dominated by the corrosion component of the attack. 5 Metal loss rates for coal slurries erosion corrosion of carbon steel have been reported in the range of 140 mils per year (mpy) at velocities of about $3 \mathrm{ft} / \mathrm{sec}$ to $450 \mathrm{mpy}$ at about $20 \mathrm{ft} / \mathrm{sec}^{5}$ These very high rates can be substantially reduced by corrosion control measures, such as adding inhibitors, applying a cathodic potential, and deaerating the slurry (i.e., removing the oxygen which supports the cathodic reaction). ${ }^{6}$ For example, the addition of chromate to an $11 \mathrm{ft} / \mathrm{sec}$ sand slurry reduced the metal loss rate in ASTM A53 carbon steel from 800 mpy to 20 mpy. 7

Postlethwaite and co-workers have investigated the erosion corrosion of carbon steel in sand slurries. They concluded that an inhibitor-induced reduction of the corrosion component of total metal loss or wear led to reduced erosion losses as well, by preserving a smoother metallic surface. 8 A smoother surface receives the impacts of slurry particles at lower average angles than does a rough surface and is less likely to loose small fragments as a result of those impacts.

Another result of the sand slurry erosion studies was the observation of a critical velocity in certain slurry-steel systems. ${ }^{9}$ Critical velocities ranged from 3 to $8 \mathrm{ft} / \mathrm{sec}$ and marked the significant increase in metal loss rate above that observed at low velocity. The critical velocities belong to the range described as "low intensity hydrodynamic" conditions, where protective films but not the underlying metal are damaged. The concept of a critical velocity is similar to that of a "breakaway velocity" at which protective oxide films are stripped away by mechanical action. 10 The average velocity developed by quad-volute slurry pumps is in the range of observed critical velocities in slurry-steel systems.

There are considerable differences between mineral slurries studied in much of the erosion corrosion literature and SRS high-level radioactive waste slurries. The differences arise from the composition of the liquid phase of the slurries and from the characteristics of the hard particles which cause erosion. The aqueous chemistry of mineral slurries is very dilute compared to that of high-level radioactive wastes. Chloride and sulfate are present, but in low concentration, and the $\mathrm{pH}$ is only slightly alkaline. The lower $\mathrm{pH}$ tends to render the typical mineral slurries much more corrosive compared to the high- $\mathrm{pH}$ radioactive waste slurries. In fact, the general corrosion rate of waste tank steel exposed to highly alkaline solutions is essentially zero, as demonstrated by ultrasonic measurements of tank wall thickness. ${ }^{11}$ Because of the reported dominance of the corrosion factor in erosion corrosion in carbon steei exposed to aqueous slurries, the near-zero general corrosion rate of waste tank steel should translate to a very low erosion corrosion rate. The solid particles in coal slurries are predominantly $\mathrm{SiO}_{2}$, which is much more abrasive than the constituents of SRS waste sludge.12 Since erosion depends upon the hardness and particle size, the harder mineral slurries should be much more aggressive than SRS sludge slurries. Erosion corrosion rates in SRS waste tanks are expected to be well below those reported in the literature for carbon steel exposed to mineral slurries. 


\section{Erosion Corrosion in Simulated Hanford Waste}

The only study of erosion corrosion of carbon steel in solutions resembling the liquid phase of SRS sludge waste was performed by Smith and Elmore on simulated Hanford wastes. 13 They investigated the erosion corrosion of ASTM A537 carbon steel exposed to simulants of "neutralized cladding removal waste" (NCRW) and "neutralized current acid waste" (NCAW). NCRW is composed primarily of zirconium-based solids and contains higher concentrations of fluoride than nitrate. NCAW is a Purex process waste, high in aluminum and iron solids and more concentrated in nitrate than fluoride. Both simulants contained about $0.1 \mathrm{M}$ free hydroxide. Thus, the simulated NCAW more closely resembled SRS Purex and HM sludge wastes than did NCRW.

The test velocities at the point of specimen contact were 4,8 , and $15 \mathrm{ft} / \mathrm{sec}$ for the NCAW experiments and 3.6, 14.4, and $54.5 \mathrm{ft} / \mathrm{sec}$ for the NCRW experiments. Test temperatures were $102^{\circ} \mathrm{C}$ for the NCAW measurements and $82^{\circ} \mathrm{C}$ for the NCRW measurements. Control coupons were located in the simulants away from the slurry jet and under stagnant conditions.

The velocities calculated for the $4000 \mathrm{gpm}$ quad-volute slurry pumps installed in some SRS waste tanks are within the velocity range of the Hanford tests. If the 2000gpm-per-nozzle, quad-volute pump is located $1.5 \mathrm{ft}$ above the tank floor (the minimum separation between the nozzle and the tank bottom), the expanding jet will contact the tank floor with a velocity of $4.7 \mathrm{ft} / \mathrm{sec}$ at a distance of $6 \mathrm{ft}$ from the nozzle. 3 The jet velocity is highest at the jet centerline. Thus, at the wall area nearest to a pump nozzle, the slurry velocity is calculated to range from about $6 \mathrm{ft} / \mathrm{sec}$ at the centerline to $2 \mathrm{ft} / \mathrm{sec}$ at the outer region of the jet. Waste tank cooling coils will experience much higher velocities due to their proximity $(<1 \mathrm{ft})$ to the pump nozzles; however, slurry velocities were not calculated in Reference 3 at distances less than $2 \mathrm{ft}$ from the nozzle.

The Hanford test temperatures were much higher than the anticipated operating temperatures in SRS waste tanks. The maximum allowed ESP waste temperature is $60^{\circ} \mathrm{C}$, which is more than $40^{\circ} \mathrm{C}$ below the NCAW solution temperature in the Hanford tests. Such a temperature difference would be expected to yield a substantial reduction in corrosion rate. Thus the Hanford test conditions were more aggressive compared to SRS tank conditions.

The results of weight loss measurements of the coupons exposed to the slurry jet reveal a slight increase in metal loss rate as compared to the stagnant slurry controls. The time-averaged corrosion rate for the 8 -ft/sec NCAW test was $2.4 \mathrm{mpy}$, and for the NCRW test at $3.6 \mathrm{ft} / \mathrm{sec}$ the rate was $1.5 \mathrm{mpy}$. Control coupons which were immersed in stagnant test solution averaged a metal loss rate of $0.3 \mathrm{mpy}$. All rates were measured with initially unoxidized specimens, and so incorporate relatively higher rates before the establishment of a presumed steady-state rate. The rate measured at the highest jet velocity was still only $4 \mathrm{mpy}$. The authors interpreted these rates as conservative upper bounds. 13 


\section{CONCLUSIONS}

Carbon steels are the most susceptible ferrous alloys to erosion corrosion. Exposed to moderate velocities of uninhibited mineral slurries, carbon steel may experience a total metal loss rate of nearly $1000 \mathrm{mpy}$. However the electrochemical (corrosion) component of metal loss dominates the mechanical (erosion) component. Controlling the corrosion component yields substantial reduction in erosion corrosion. Hence neutral-pH, corrosion-inhibited mineral slurries show velocity-independent corrosion rates of the order of $20 \mathrm{mpy}$.

Highly alkaline radioactive wastes stored in carbon steel tanks are inhibited to prevent stress corrosion cracking and pitting corrosion. The required inhibitor levels result in a near-zero general corrosion rate for carbon steel. The erosion corrosion experiments performed on simulated Hanford radioactive waste revealed total metal loss rates of just a few mpy.

SRS high-level waste is of a composition similar to the Hanford test slurries, will be pumped at velocities similar to those tested, but will be maintained at temperatures more than $20^{\circ} \mathrm{C}$ below the Hanford test temperatures. The likely result for SRS waste tanks is a lower metal loss rate. Given the 2.4-mpy rate in the Hanford NCAW tests at $102^{\circ} \mathrm{C}$ on unoxidized, ground coupons, the metal loss rate for SRS tanks under jet mixing conditions at $\leq 60^{\circ} \mathrm{C}$ will probably be $<1 \mathrm{mpy}$. The actual metal loss in one year of ESP operations will be reduced proportionally to the slurry pumps' time of operation. Erosion corrosion under reported slurry pump operations is therefore not expected to degrade the primary vessel of SRS waste tanks.

\section{REFERENCES}

1. Mars G. Fontana and Norbert D. Greene, Corrosion Engineering, 2nd Ed., McGraw Hill Book Company, New York, 1978.

2. Metals Handbook Ninth Edition, Volumes 11 and 13, ASM International, Metals Park, Ohio, 1987.

3. Gary Tatterson, "Jet Mixing in In-Tank Processing (U)," DPST-89-380.

4. Brijesh Vyas, "Erosion-Corrosion," in Treatise on Materials Science and Technology, Volume 16, Erosion, C. M. Preece, ed., Academic Press, New York (1979).

5. G. Cragnolino, C Czajkowski, and W. J. Shack, "Review of Erosion-Corrosion in Single-Phase Flows," NUREG/CR-5156, ANL-88-25, Argonne National Laboratory, 1988.

6. G. R. Hoey and J. S. Bednar, "Erosion-Corrosion of Selected Metals in Coal Washing Plant Environments," Materials Performance, vol. 22, 9, April, 1983.

7. A. V. Levy, N. Jee, and G. Sorell, "Erosivity of Coal Particles in Coal Solvent Slurries," in Slurry Erosion: Uses, Applications, and Test Methods, ASTM STP 
946, J. E. Miller and F. E. Schmidt, Jr., eds., American Society for Testing and Materials, Philadelphia (1987).

8. J. Postlethwaite, Corrosion, Vol. 37, p. 1, 1981.

9. J. Postlethwaite, E. B. Tinker, and M. W. Hawrylak, Corrosion, Vol. 30, p. 285, 1974.

10. B. C. Syrett, Corrosion, Vol. 32, p. 242, 1976.

11. F. G. McNatt, "Annual Radioactive Waste Tank Inspection Program 1991 (U), WSRC-TR-92-166 Rev. 1, October 1, 1992.

12. White Rock Engineering, Inc., "Report on Abrasivity Tests on Five Metal Materials for DuPont de Nemours Company," May 21, 1987.

13. H. D. Smith and M. R. Elmore, "Corrosion of Carbon Steel under Impinging Jets of Simulated Slurries of Neutralized Current Acid Waste (NCAW) and Neutralized Cladding Removal Waste (NCRW)," PNL-7816, Pacific Northwest Laboratory, January, 1992. 
Ms. W. F. Perrin, Technical Information Officer

U. S. Department of Energy

Savannah River Operations Office

Aiken, SC 29801

Dear Ms. Perrin:

\section{REQUEST FOR APPROVAL TO RELEASE SCIENTIFIC/TECHNICAL INFORMATION}

The attached document is submitted for classification and technical approvals for the purpose of external release. Please complete Part II of this letter and return the letter to the undersigned by 03/04/94 . Patent clearance, if necessary, is requested and recelved via direct communications between this office and the DOE-SR Patent Counsel. The document has been reviewed for classification by a WSRC classification staff member and has been determined to be Unclassified

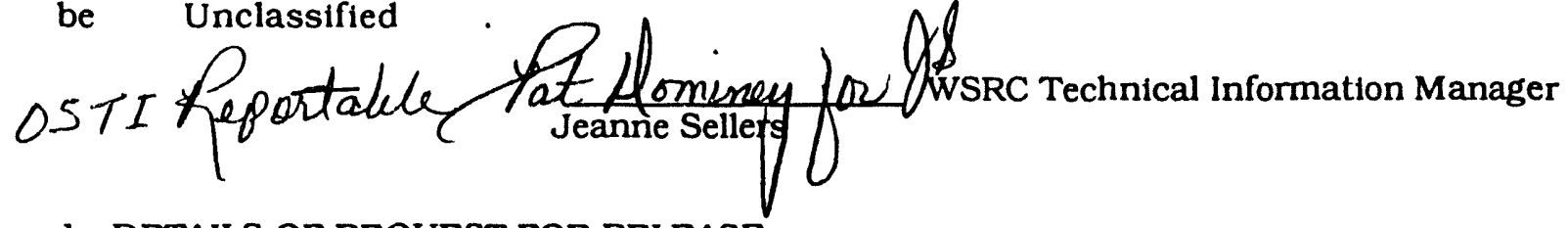

1. DETAILS OF REQUEST FOR RELEASE

Document Number: WSRC-TR-93-595

Pub Deadline:

Author's Name: P. E. Zapp

Location: 773-A, C-117

Document TItle: POTENTIAL FOR EROSION CORROSION OF SRS HIGH LEVEL WASTE TANKS (U)

Manager's Name: N. C. lyer

Department: Materials Technology Section

A technical deliverable being deposited to OSTI for unlimited distribution to the general public. Technical questions pertaining to the contents of this document should be addressed to the author(s) or the Manager. Questions concerning the processing of this document should be addressed to the WSRC Technical Information Manager, 5-3992 or 5-2099/5-3384.

II. DOE-SR ACTION

Date Received by TIO

$01-21-94$

Approved

$\square$ Not Approved

$\square$ Approved Upon Completion of Changes

$\square$ Revise and Resubmit to DOE

$\square$ Approved with Remarks

Remarks

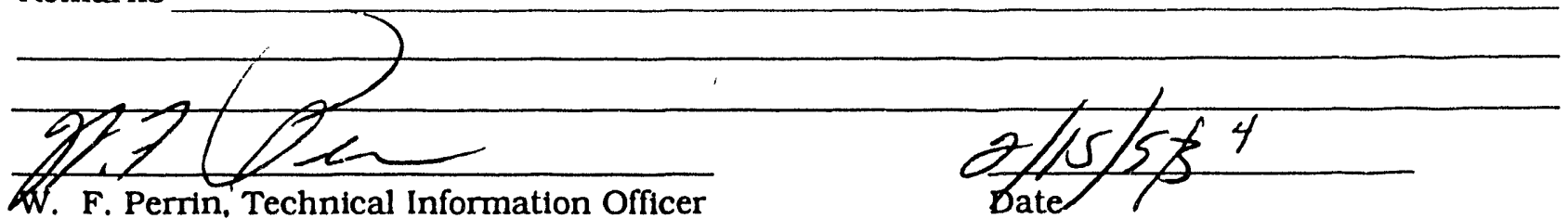

DOE-SR 


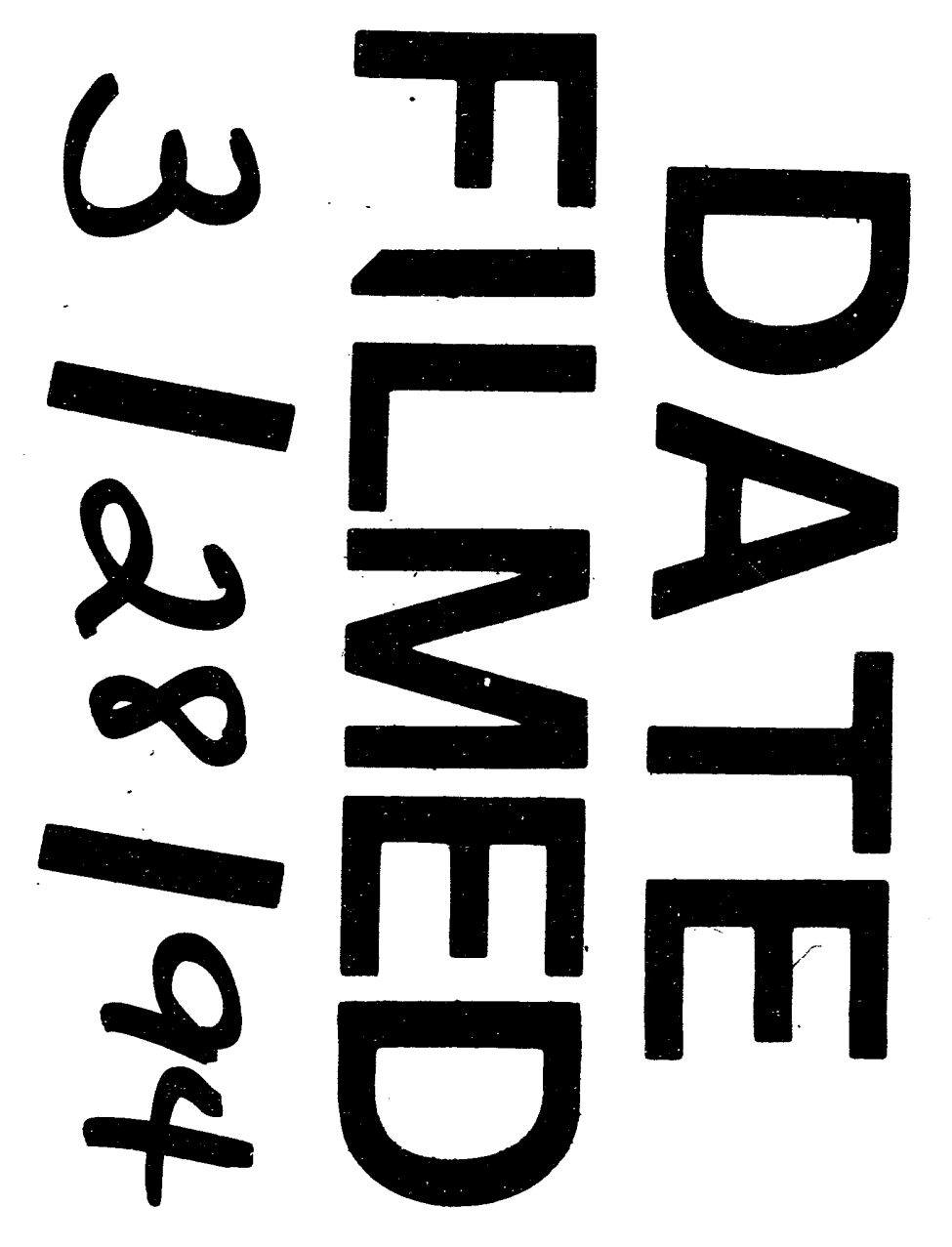

1 


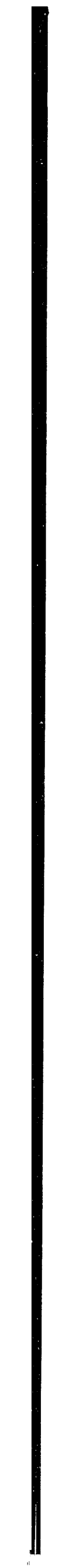

